\section{Wired for Sound}

The activities made possible in a college library by a Fine Arts Study are brought out in this account by the librarian of Drew University.

$\mathrm{I}^{\mathrm{N}}$ ACCORDANCE with hoary traditions, one expects libraries to be wired for silence and not for sound. Perhaps the library here dealt with has departed from this pattern. As a matter of fact, those responsible for the special facilities in the library of Drew University hoped that the building would be wired for both silence and sound.

The Fine Arts Study was included in the plans of the Rose Memorial Library because the librarian believed that a university library should provide opportunities for enjoying great pictures and fine music.

The room designated as the Fine Arts Study is on the third floor. It measures twenty-seven by twenty-five feet. The walls are covered with cork, the ceiling with macoustik plaster, and the floor with rubber tile. The cork covering on the walls makes possible the use of thumb tacks for the temporary hanging of prints. It also assists in making the room soundproof. The special plaster adds to the acoustical qualities of the room. Four ceiling fixtures furnish indirect general illumination. Holophane light troughs flush with the ceiling provide special illumination for the walls when pictures are on display. A folding blackboard built into one wall is used as an instructional aid but is invisible when not in use. Two listening booths, each five by eight feet, afford listening facilities for broadcast and recorded music. The walls of each booth are covered with acoustical celotex. One booth which has been designated for individual listening has been equipped with an up-to-date model of a radio-phonograph with a recording attachment. The other booth houses a more complicated and more powerful radio-phonograph, with two turntables and microphone equipment. From this machine conduits lead to five outlets, to provide for group listening. The first is in one of the walls of the Fine Arts Study, the second in the other listening booth, the third in the William S. Pilling Room (browsing room), the fourth in the main hall of the library, and the fifth in the library staff room. Into the outlet of the Fine Arts Study a speaker has been permanently installed; into the outlet of the other listening booth an outdoor speaker can be plugged for special occasions; and into the other outlets a portable speaker can be plugged. For classes meeting in the study, thirty-six folding chairs provide adequate seating capacity and make possible an easy clearing of the room when it is needed for an art exhibit.

Before the Rose Memorial Library was erected, Brothers College offered courses in the history of art and music. A radiophonograph, a record library, and a collection of prints were then housed in the college building. In cooperation with the college the librarian made the new facilities available, and the college department of fine arts was moved into the Fine Arts Study of the library. The students of that department were to use the listening equipment and other facilities of the study. 


\section{Purposes}

When the Rose Memorial Library was opened, the Fine Arts Study had several definite purposes. The college classes in the history of art and music received their instruction there; at scheduled periods individual students of the college and theological seminary listened to broadcast and recorded music; and musicales were presented to groups in the browsing room through the portable speaker mentioned above. After a few months, a group of students interested in dramatics began to produce and to present a series of radio plays.

During two academic years two series of musicales called "Evenings with the Composers" were presented by the librarian. With Bach's Arioso as the theme music, one-hour programs were given after the campus dinner hour. The first series consisted of the compositions of Beethoven, Mozart, Schubert, and Wagner, concluding with a request program. The second featured compositions of Mendelssohn, Purcell, and Herbert. A request program concluded this series. As a part of both cycles, Handel's oratorio, the Messiah, was presented as a Christmas program. During the first year the Good Friday music from Parsifal was given at Easter. It was repeated in the next year and with it was presented a one-act play, The Two Thieves by Esther Willard Bates.

Occasionally there are radio programs which the librarian and teaching faculty feel ought to be made available to students. Some of these are definitely related to courses of instruction. For example, the college class in argumentation and debate has met in the Fine Arts Study in order to listen to the Town Meeting of the Air. After the broadcasts the members have discussed the topics scheduled for those meetings. Groups of students met in the li- brary to listen to another series of broadcasts not as closely bearing upon a course of instruction and yet definitely related to college life. This series was the Brothers College Hour, a college publicity program broadcast from Newburgh, N.Y. Another group of programs touching more closely the purpose of the Fine Arts Study was the all-Beethoven series given by the National Broadcasting Company Symphony Orchestra. The students were invited to come to the browsing room after closing time on Saturday night. Around the lighted fireplace small groups, with the librarian and other members of the faculty, listened to Toscanini's interpretations of all nine of Beethoven's symphonies. Speaking of these evenings, one student said, "This sort of thing contributes to the beautiful memories of college days."

Still another group of activities is made possible by a recording attachment on the smaller radio-phonograph. Some of these are pertinent to the programs of instruction in the theological seminary and in the college. The others are mostly extracurricular in character.

\section{For Speech Instruction}

The speech instructors in the seminary and college use the recording equipment to measure the progress of speech students. Recordings are made near the beginning of instruction and at various times through the year. In this part of their program the instructors follow two methods. Sometimes the process is handled individually and sometimes the entire class meets in the Fine Arts Study, sharing in the experiences of recording and in hearing the play-back.

The division of religious education in Drew Theological Seminary made use of these facilities about three years ago to summarize two projects. One of the projects originated in a course on the use of 
the Bible in religious education. Through narration and dramatization, groups of students recorded the story of the making of the Bible. The other project originated in the course called Practicum in Method in . Teaching Religion. Pupils of a weekday demonstration school of religion recorded the summary of their experiences in that school.

Recordings have been made of various extra-classroom activities. Last year the college band made one before its members were caught in the draft. The Seminary Players recorded their Easter play. Selected recordings were made of the Brothers College weekly broadcasts from Newburgh, N.Y.

From time to time individual recordings are made. Some students like to make them of speeches or songs, to send home to their parents. This sort of thing has been very popular since the declaration of war.

The actual presentation of musicales and dramatics has been gradually passing out of the hands of the librarian into the hands of student groups. The students of Drew Theological Seminary render Handel's Messiah at Christmastime and Stainer's Crucifixion at Easter. Seminary Players present at least two plays during the year and between seasons use the sound equipment for play rehearsals and for developing microphone technique. The students of Brothers College had a radio dramatics group before the war and gave at least two plays a year.

Very little has been said so far about the art program originating in the Fine Arts Study. In addition to the collection of prints on file in that room and exhibited to classes as an integral part of their courses, loan collections are presented from time to time. The most significant so far have been those loaned by the Metropolitan Museum of Art, Knoedler, and Herbert MacDonald.
Color prints were lent by the museum, sixteenth century etchings by Knoedler, and Mr. MacDonald, a graduate of Drew Theological Seminary, loaned an excellent group of his own paintings. This collection was so large that the exhibition cases in the main hall of the library were also used to display them.

At the present time, and this will maintain between exhibitions of loan collections, the walls are hung with framed color prints from the college collection. In addition to these there are displayed on the tops of bookcases and record cases a small collection of Chinese objets d'art.

\section{The Record Collection}

In the record collection there are to be found the sonatas, concertos, symphonies, chorals, operas, and all other musical forms of ancient and modern composers. Through the card catalog in the room, it is possible to locate pieces by composer, title, artist, whether ensemble or soloist, and conductor. A growing repertoire of scores contributes to intelligent listening by groups or individuals. As a further aid to musical enjoyment and to artistic enjoyment, there is a small collection of books-about one hundred-on the history of music and art.

During the present emergency, when academic programs are in the whirl of acceleration, the Fine Arts Study has not escaped. The fate of the college dramatics group has already been mentioned. The regularly-scheduled monthly musicale has been discontinued also. Individual listening still goes on. A special Christmas feature, not mentioned above, but recognized almost as a tradition, will no doubt continue-that is, the playing of recorded chimes through an outdoor speaker. The campus population and the residents of Madison have expressed their appreciation of this part of the program. 
There might still be some doubts in readers' minds as to the wisdom of incorporating sound equipment into plans for college or university library buildings. Perhaps this article has been too objective. After some five years' experience, what would I recommend? What would I do if the Rose Memorial Library were being planned now? Would there still be a Fine Arts Study in the plans? Would I advise other librarians to include such a department in plans for their libraries? My answer to the first two questions is in the affirmative. To the third question the answer depends on certain conditions. If the library can provide adequate supervision for the Fine Arts Study during individual listening time, my answer is in the affirmative. It is in the negative if that supervision cannot be provided. The equipment, the record collection, and the art collection represent too much of an investment to be entrusted to the occasional careless student who might be using the room.

Whenever listening periods are scheduled there ought to be a member of the library staff on duty. This attendant should guide inexperienced listeners in the use of the equipment and should see to it that the equipment and materials are properly used.

What type of equipment would I recommend? At Drew we have learned much on this subject, thanks to an honest radio man who is a sound engineer. With the exception of the original radio receiver on the larger radio-phonograph, very little of the original installation remains. The amplifier has been almost entirely rebuilt and the original phonograph has been discarded long since. If we had known in 1938 what we have since learned, we would have commissioned our radio man to assemble or build the equipment. The tonal qualities would have been better from the outset and the price would have been about 50 per cent less. The smaller machine which was purchased on his advice does not have the tonal qualities which he has built into the other machine, but his honesty saved us from making another mistake and we have found the equipment satisfactory. Although the names of manufacturers have been withheld in this article, that and any other helpful information may be obtained from the writer.

The Fine Arts Study does not represent a purely localized group of activities. It indicates a librarian's conviction concerning the library's relationship to a campus program. That is why not only the room carrying this label but the browsing room, known as the William S. Pilling Room, is made available to groups who choose to listen to fine music. During the current year that room is being used for a series of concerts under the sponsorship of Brothers College. In the fall, recitals were given by Frances Magnus, a violinist, and by Ruth Geiger, a pianist. In the spring the series concluded with Ardyth Walker, a cellist. Audiences of some two hundred listeners from the campus and community attend these concerts.

In its fine arts programs, the Rose Memorial Library of Drew University serves the university students and faculty primarily, but friends in the community are often invited to share in the enjoyment of its programs. Some community organizations occasionally use the facilities for their own programs. 